\title{
TEMPOS QUENTES PARA A ESTRATÉGIA EMPRESARIAL
}

\section{Por Paulo Cesar Vaz Guimarães}

Professor do Departamento de Administração, Fundação Escola de Sociologia e Política de São Paulo. E-mail: ota@terra.com.br

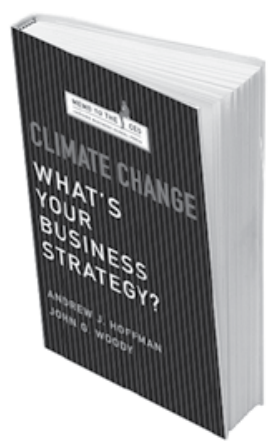

\section{CLIMATE CHANGE: WHAT'S YOUR BUSINESS STRATEGY?}

De Andrew J. Hoffman, John G. Woody

Boston: Harvard Business Press, 2008. 115 p.
A edição de 17 de agosto de 2006 do semanário The Economist traz uma divertida charge mostrando um opulento capitalista sendo atenciosamente servido por um mordomo. Dentre os quitutes oferecidos, que incluíam os ícones de consumo mais procurados pela elite econômica, principalmente, estava um dos mais arrojados produtos do mercado financeiro: os derivativos. Ao ler a reportagem, descobre-se que a sátira enfatiza o interesse dos bancos de investimento em cooptar a classe dos milionários, que cresceu de forma sensível em todo o mundo. Nessa competição pelos bem aquinhoados, toda sorte de mimos é válida: champanhe de primeira linha, decoração assinada por famosos arquitetos, coleções de artefatos históricos, entre outros. Um desses afagos, porém, ganha destaque, pois é consequêencia dos tempos atuais: a indicação da leitura do livro Field Notes from a Catastrophe: Man, Nature, and Climate Change. A autora, Elizabeth Kolbert, jornalista da revista New Yorker, conseguiu com habilidade relatar ocorrências em diversas partes do globo que sugerem problemas ad- vindos das mudanças climáticas. A partir de seu arrazoado, faz um alerta para o provável colapso que se avizinha, salvo se alterações forem feitas nos processos de produção e consumo de bens e serviços. A indagação que surge é: qual o sentido de essa peça literária estar na sala de visitas do edifício chamado capitalismo, posta pelo seu principal executivo, a empresa moderna?

Para aqueles interessados em melhor compreender esse contexto em que as estratégias empresariais ocorrem, mais no exterior, porém também no Brasil, a leitura da obra Climate Change: What's Your Business Strategy? de Andrew Hoffman e John Woody, é oportuna. Nela, percebe-se um esforço para sintetizar os principais acontecimentos relativos às mudanças climáticas que influenciam o mundo corporativo, tais como as novas regulamentações, o preço da energia e os desastres ambientais. Prestando-se mais aos dirigentes das empresas, pois é um guia que fornece um arcabouço analítico para a avaliação da situação da empresa diante desse problema ambiental, os autores se apóiam em casos concretos para informar os assuntos que permeiam a intersecção das estratégias empresariais e as mudanças climáticas, construindo uma argumentação consistente e clara.

Esses autores estão em uma posição de destaque para sustentar a empreitada a que se propuseram, decorrência da experiência obtida no contato com uma grande diversidade de empresas e da intensa pesquisa no ambiente acadêmico. Andrew Hoffman, em particular, pode ser considerado um dos profissionais mais profícuos no tema desde a publicação de sua tese de doutorado, no final dos anos 1990, oportunidade em que adotou uma abordagem institucionalista inovadora na análise do histórico do ambientalismo, privilegiando a perspectiva das firmas, o que não era freqüente. De sua cátedra na Universidade de Michigan, tem divulgado e criticado as diferentes estratégias adotadas pelas empresas na incorporação da dimensão ambiental (mudanças de processo, novos produtos, mensuração de custos etc.), recorrendo a múltiplos prismas de análise, desde as alternativas tecnoló- 
gicas até os aspectos psicológicos que necessitam ser superados para a lide das mudanças climáticas.

A partir daí, os autores formulam a tese central que norteia o trabalho, qual seja, de que as mudanças climáticas afetarão todas as empresas, mas de forma distinta: algumas serão radicalmente atingidas enquanto outras sofrerão tangencialmente; algumas auferirão ganhos e outras terão prejuízos, de magnitudes variadas. Ou seja, não é uma panacéia e sim uma nova variável do mercado que deve entrar no processo decisório. Assim, os autores repassaram as implicações das mudanças climáticas para os negócios, salientando os eventos internacionais mais recentes e os riscos associados, tais quais os de natureza regulatória, legal, econômica e de reputação. $\mathrm{Na}$ seqüencia, estruturam um conjunto de passos para o dirigente identificar as condições de sua empresa e formular uma estratégia adequada.

Não obstante os percalços e avanços específicos, os autores destacam a necessidade de os atores econômicos avaliarem sua exposição no novo cenário externo. Para tanto, torna-se inexorável, como primeiro passo, a realização de inventários, de forma a balizar as estratégias. Sem esse mecanismo, Hoffman e Woody alertam para a idéia de que não haverá como montar um sistema de informações que colabore na identificação de riscos e oportunidades nas operações e produtos, nem como parametrizar o posicionamento da empresa diante de seus concorrentes. Aparentemente, esse passo inicial ainda está por ser dado, já que a mobilização das empresas é tênue no que diz respeito às ações concretas. Objetivamente, uma pesquisa posterior à redação do livro, realizada pela McKinsey em dezembro de 2007, ao consultar empresários de todo o globo, revelou que mais de $60 \%$ deles dizem ser importante a consideração das questões ambientais; contudo, apenas um terço efetivamente realiza algo a esse respeito. Diante de tamanho imobilismo, o que se pode inferir é que a alta administração não está instrumentalizada para agir, caracterizando uma situação de risco aos acionistas e aos interessados no trabalho da empresa.

Para quem fez essa primeira "lição de casa", o único conforto será a disponibilidade de dados para subsidiar as suas ações concretas, segundo passo a ser dado pelas organizações. Apoiando-se nas declarações dos próprios empresários, como o CEO da Duke Energy, os autores asseveram que as oportunidades a serem aproveitadas normalmente não estão visíveis e exigem um amplo esforço de investigação. Para transformar seu potencial em medidas efetivas, a organização precisa adaptar-se, devendo mudar valores e práticas, bem como desenhar novos procedimentos. É claro que os empresários têm noção dessas dificuldades, como atesta a revista The Economist, que em 2008 divulgou uma pesquisa identificando barreiras internas como os maiores obstáculos para a difusão da sustentabilidade: falta de conhecimento para desenvolver metas e formas de controle, desalinhamento da estratégia ambiental com as demais, e falta de clareza da direção sobre o assunto. Todavia, o discernimento não é suficiente, e com isso as iniciativas de transformação não são a regra.

Após a implantação das ações, o passo seguinte é o mais sensível, pois consiste na tentativa de influenciar o processo de formulação das políticas públicas. A idéia é que as empresas tenham uma participação ativa na estruturação da regulamentação que disciplina sua existência, e, para tanto, devem monitorar os ambientes institucionais onde isso ocorre, em seu país ou alhures. O ponto nevrálgico é que nesse navio só poderão embarcar aqueles que tiverem cumprido os passos anteriores e que se legitimem enquanto interlocutores capazes, notadamente no sentido de aperfeiçoar o quadro regulatório. Cabe reconhecer que as empresas sempre procuraram interceder nas decisões que alteram as regras do jogo, mas aqui há um ar de novidade ao solicitar que isso transcorra no espaço público. Os autores foram também felizes ao tocar em uma questão crucial para o Brasil. Se nossos empresários possuem alguma dúvida de que o risco de uma regulamentação específica para as mudanças climáticas chegue a termo, é bom saber que outra pesquisa da McKinsey, realizada em 2008 junto aos consumidores de diversos países, mostrou que $30 \%$ deles clamaram pelo incremento da regulamentação pública sobre as empresas e as emissões de poluentes. Apenas no nosso país, $70 \%$ dos consumidores apontaram a medida como fundamental. É patente que possuímos alguma idiossincrasia a ser entendida, mas independentemente de sua explicação, a probabilidade de o governo vir a atuar é grande. Aqui, mais do que lá fora, vale o adágio citado por Hoffman e Woody: "Se você não está servido à mesa, você consta do cardápio".

Os autores ficaram devendo uma análise destinada àqueles afetados pela atividade corporativa. Ao longo da leitura, a exemplo da parte inicial sobre o inventário, fica difícil entender como as empresas ainda não mudaram seu comportamento diante das questões acerca das mudanças climáticas, considerando que muitas das medidas passíveis de implementação otimizariam o uso dos fatores de produção (por exemplo, consumo de energia), com repercussões positivas na lucratividade. Como há essa inação, os autores muito contribuiriam auxiliando os demais atores a encontrar formas de pressão para que o setor empresarial reaja ao desafio de não comprometer as condições ambientais do planeta. 